\title{
HOW REASONABLE IS THE 'REASONABLE' ROYALTY RATE? \\ DAMAGE RULES AND PROBABILISTIC INTELLECTUAL PROPERTY RIGHTS
}

\author{
JAY PIL CHOI \\ CESIFO WORKING PAPER NO. 1778 \\ CATEGORY 9: INDUSTRIAL ORGANISATION \\ August 2006 \\ Presented at CESifo Area Conference on \\ ApPlied Microeconomics, MARCH 2006 \\ An electronic version of the paper may be downloaded \\ - from the SSRN website: \\ www.SSRN.com \\ - from the RePEc website: \\ www.RePEc.org \\ - from the CESifo website: \\ www.CESifo-group.de
}




\title{
HOW REASONABLE IS THE 'REASONABLE' ROYALTY RATE? \\ DAMAGE RULES AND PROBABILISTIC INTELLECTUAL PROPERTY RIGHTS
}

\begin{abstract}
This paper investigates how different damage rules in patent infringement cases shape competition when intellectual property rights are probabilistic. I develop a simple model of oligopolistic competition to compare two main liability doctrines that have been used in the US to assess infringement damages - the unjust enrichment rule and the lost profit rule. It also points out the logical inconsistency in the concept of the "reasonable royalty rates" when intellectual property rights are not ironclad.
\end{abstract}

JEL Code: O3, L1, L4, D8, K4.

Keywords: probabilistic intellectual property rights, damage rules, reasonable royalty rates.

\author{
Jay Pil Choi \\ Department of Economics \\ Michigan State University \\ East Lansing, MI 48824 \\ USA \\ choijay@msu.edu
}

December 2005

Revised June 2006

I thank Laurent Linnemer and participants in the CESifo Area Conference on Applied Microeconomics for useful comments and discussions. All remaining errors are my own. 


\section{Introduction}

This paper investigates how different damage rules in patent infringement cases shape competition when intellectual property rights are probabilistic. Most of the literature on patent protection assumes ironclad patents and no uncertainty regarding patent claims. ${ }^{1}$ The analysis of damage rules in the literature also seems to implicitly assume no uncertainty. This is puzzling in that there would be no infringement to speak of with ironclad patents under the damage rules adopted in the US and analyzed below. Therefore, I develop a simple model of oligopolistic competition that incorporates the probabilistic nature of patents. I also point out the logical inconsistency in the concept of the "reasonable royalty rates” when intellectual property rights are not ironclad.

Patent infringement damages are intended to protect intellectual property rights and compensate for the pecuniary loss that the patentholder has suffered from the infringement. In the US, there are two main liability doctrines that have been used to assess infringement damages. The "unjust enrichment” rule aims at deterring theft of intellectual property right by punishing the infringer who is required to disgorge all the profits from the infringement. This doctrine was mainly used in the assessment of damages up until the 1946 Amendment of Patent Act. Since then US courts have shifted towards the "lost profit" doctrine that is compensatory in nature. It intends to make the patentee "whole" by enforcing the defendant to make up for the difference between the patentee's pecuniary condition that would have been without infringement and the one after the infringement. ${ }^{2}$ Often the courts seem to conclude that all these approaches yield more or less the same estimate or similar effects, if implemented correctly. The aim of

\footnotetext{
${ }^{1}$ Recently, however, more attention has been paid to the probabilistic nature of patent protection and its implications for competition. See Lemley and Shapiro (2005) for recent analyses of probabilistic patent protection.

${ }^{2}$ Currently in the US, economic damages in patent infringement litigation are based on Title 35, Section 284 of U.S. Code, which mandates that damages be adequate to compensate for the infringement, but no less than a reasonable royalty rate for the use of the subject patented invention.
} 
this paper is to analyze how these different damage rules affect competition in different ways and to understand what factors derive the differences.

Considering the recent explosion in patent litigation and increasingly important role of intellectual property rights as a competitive strategy, it is important to understand the impact of different damage rules on market competition. ${ }^{3}$ Even thought there is a long standing interest and extensive discussions on patent damage rules in the law literature, formal and rigorous economics analyses on this issue are virtually non-existent with the exceptions of Shankerman and Scotchmer (2001) and Anton and Yao (forthcoming).

More specifically, I consider a duopolistic competition with a patent holder of product innovation and a potential infringer. Until recently, the existing literature on innovation typically assumed ironclad patents that are assumed to be valid with certainty and a well-defined scope of protection. In reality, however, most patents issued face a significant amount of uncertainty in terms of their commercial value, validity, and scope of protection. I thus develop a model that explicitly accounts for the uncertain nature of patents. ${ }^{4}$ In fact, in my basic model which assumes product innovation and equal production cost, there will be no infringement under the damage rules analyzed below if ironclad patents are assumed. Both the paten holder and potential infringer are aware of the probabilistic nature of patents and compete in the shadow of litigation in that the amount of damages to be paid in the case of infringement depend on the strategies taken in the market place. The set-up of the model reflects the fact that a significant number of infringements can go undetected for more than a nominal period of time and the resolution of disputes entails significant delays in the court system. ${ }^{5}$

\footnotetext{
3 See Bessen and Meurer (2005).

4 See Lemley and Shapiro (2005) for an excellent discussion of probabilistic patents. They discuss implications of patent litigation uncertainty and potential reforms of the current patent system in the US. However, they do not analyze and compare the effects of different damage rules on market competition. 5 See Crampes and Langinier (2002) for a model in which the patentholder invests in monitoring to supervise the market and detect infringement.
} 
The main model of Shankerman and Scotchmer (2001) considers a vertical relationship in which a patent on research tools is licensed to a potential infringer who can develop a commercial product. However, they analyze ironclad patents and show that the lost profit/reasonable royalty rate damage rule suffers from a multiplicity of equilibrium due to the circularity of logic inherent in the concept. In contrast, I consider a probabilistic patent and the non-existence of a "reasonable" royalty rate that is consistent with the logic. ${ }^{6}$

This paper is very closely related to Anton and Yao (forthcoming) who independently developed an equilibrium oligopoly model of patent infringement in which they analyze the impact of patent infringement damages on market competition. They consider a process innovation and provide an in-depth analysis of the lost profit measure of damages. In contrast, I analyze a product innovation and the focus of my paper is on the comparison of different damage rules. ${ }^{7}$ The difference in the nature of innovation product or process innovation - across these two papers turns out to be important. The process innovation implicitly assumes the availability of substitute technologies. In particular, it allows a "passive” form of infringement under the lost profit rule, in which the imitator infringes and produces at a lower cost, but at the output level that would have been produced without infringement. This type of infringement can lead to no lost profits for the patentholder and complicates their analysis. However, such infringement strategy is ruled out under product innovation. In sum, my paper and Anton and Yao (2005) focus on different types of innovation and different aspects of damage rules. These two papers

\footnotetext{
6 Shankerman and Scotchmer (2001) also consider a model in which the patentholder is able to develop the commercial product herself and infringement can lead to a race between the patentholder and a potential infringer. However, competition takes place in the R\&D stage and there is no competition in the product market.

${ }^{7}$ Even though Anton and Yao (forthcoming) also analyze alternative damage rules, they are of secondary importance.
} 
thus can be viewed as complementary in that taken together they provide a more complete picture of the impact of damage rules on competition.

In a different vein, Ayres and Klemperer (1999) argue in favor of denying immediate injunctive relief and substituting delayed probabilistic determination with monetary damages. They show that delay and uncertainty restrict patentees' market power and induce limited infringement without substantially undermining patentees’ incentives to innovate. In addition, any shortfall in the patentees’ profits due to limited infringement can be compensated by lengthening the length of the patent. Their argument is based on the logic of the envelope theorem and the "Ramsey intuition."8 In this paper, I do not address the relative merits of delayed damage rules with uncertainty vis-à-vis injunctive relief. Instead, I take the uncertainty associated with the current damage system and substantial delay until the resolution of dispute as given, and compare the effects of different damage rules on interim competition.

The remainder of the paper is organized in the following way. In section II, I set up the basic model of competition with probabilistic patents under various rules of damages. I also extend and check the robustness of the basic model by considering the possibility of asymmetric cost structure between the patentholder and the infringer. Section III analyzes the reasonable royalty rate rule and points out the logical inconsistency of the doctrine with uncertain patents. Section IV allows ex ante licensing and analyzes how different damage rules affect the terms of ex ante licensing contracting. Concluding remarks follow in section V.

\footnotetext{
${ }^{8}$ Ramsey pricing suggests that the optimal tax structure that minimizes the deadweight loss for generating a given amount of revenue tends to tax as many goods as possible to create small distortions in broad markets. Allowing a monopoly power through the patent system is similar to imposing a tax. If each year is viewed as separate product markets, this suggests that the patent length should be infinite with the scope of patent appropriately adjusted to generate the same discounted value of monopoly profit.
} 


\section{The Model}

I consider a situation called "two-supplier world," in which a patentholder (firm 1) and a potential competitor/infringer (firm 2) are the two suppliers of the patented product. These two firms compete in the Cournot fashion with both firms simultaneously choosing quantities as a strategic variable. Let $\pi_{1}\left(q_{1}, q_{2}\right)$ and $\pi_{2}\left(q_{1}, q_{2}\right)$ be the profit level for the patentholder and the infringer, respectively, when they produce $q_{1}$ and $q_{2}$ before any ruling on damages. As standard in the literature, we assume that the strategic variables $q_{1}$ and $q_{2}$ are strategic substitutes, that is, $\frac{\partial^{2} \pi_{i}\left(q_{1}, q_{2}\right)}{\partial q_{i} \partial q_{j}}<0$.

Without any intellectual property right involved, each firm $i$ maximizes $\pi_{i}\left(q_{1}, q_{2}\right)$ with the following first order conditions:

$$
\frac{\partial \pi_{i}\left(q_{1}, q_{2}\right)}{\partial q_{i}}=0, \text { for } i=1,2
$$

which implicitly defines each firm's reaction function $q_{i}=R_{i}\left(q_{j}\right)$, where $i=1,2$ and $i \neq j$. In the absence of IPR, the Nash equilibrium outputs $\left(q_{1}^{*}, q_{2}{ }^{*}\right)$ are at the intersection of these two reaction functions. We assume that the Nash equilibrium is well-defined, unique, and interior with $q_{1} *>0$ and $q_{2} *>0$.

Now I introduce intellectual property rights in the model. Firm 1 has a patent for a product innovation. Firm 2 can produce the good either with license or by infringing the patent. We first analyze how market competition plays out assuming that firm 2 decides to infringe the patent. After the competition the court decides if firm 2 has infringed the patent. We assume that the IPR is uncertain in the sense that the infringement is found with probability $\alpha$, which is assumed to be common knowledge between the patent holder and potential infringer. ${ }^{9}$ There are many reasons for this uncertainty. For instance, the patent may be declared invalid by the courts. According to U.S. patent law, the issuance of a patent does no more than confer a patent right that is “presumed” valid (35 U.S.C.A. Sec. 282). The final responsibility for validating or invalidating the patent resides with the courts. In addition, the "doctrine of equivalents"

\footnotetext{
9 See Lemley and Shapiro (2005).
} 
entitles the patented invention to cover a certain range of equivalents. However, the exact boundary of the equivalents is impossible to draw. The matter of infringement can be reasonably assumed to be decided case by case. Finally, for process innovations, infringement may not be detected. In such a case, the probability of detection is also reflected in the parameter $\alpha$. Once the infringement is found, the court requires the infringer to compensate the patent holder for his transgression. I consider two damage rules, the unjust enrichment and the lost profit, and investigate how they affect market competition.

\section{1. Competition with Uncertain Patents under the Unjust Enrichment Rule}

In this subsection, I analyze how the patent-holder (firm 1) and the potential infringer (firm 2) compete in the product market under the "unjust enrichment” (UE) damage rule. According to the UE rule, the patentholder is entitled to recover profits earned by the infringer. Since the probability that the patent is deemed to be valid and the infringement is found is $\alpha$, the patentholder solves the following problem:

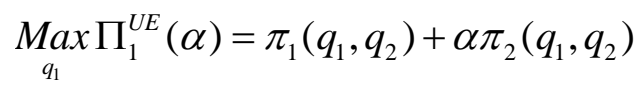

The first order condition for firm 1's optimal output $q_{1}$ is given by

$$
\frac{\partial \Pi_{1}^{U E}(\alpha)}{\partial q_{1}}=\frac{\partial \pi_{1}\left(q_{1}, q_{2}\right)}{\partial q_{1}}+\alpha \frac{\partial \pi_{2}\left(q_{1}, q_{2}\right)}{\partial q_{1}}=0,
$$

which implicitly defines firm 1 's reaction function $q_{1}=R_{1}^{U E}\left(q_{2} ; \alpha\right)$.

The potential infringer solves the following problem.

$$
\underset{q_{2}}{\operatorname{Max}} \Pi_{2}^{U E}=(1-\alpha) \pi_{2}\left(q_{1}, q_{2}\right)
$$

Notice that the potential infringer's profit under the UE rule is a scaled down version of the profit in the absence of any intellectual property rights. Thus, given $q_{1}$, the optimal choice for firm 2 is the same as in the normal Cournot competition. More precisely, the first order condition for firm 2's optimal output $q_{2}$ is given by 


$$
\frac{\partial \pi_{2}\left(q_{1}, q_{2}\right)}{\partial q_{2}}=0
$$

which implicitly defines firm 2's reaction function $q_{2}=R_{2}^{U E}\left(q_{1}\right)=R_{2}\left(q_{1}\right)$. The Nash equilibrium royalty rates $\left[q_{1}^{U E^{*}}(\alpha), q_{2}^{U E^{*}}(\alpha)\right]$ are at the intersection of these two reaction functions. We assume that the Nash equilibrium is unique and satisfies the stability condition.

Lemma 1. $\frac{q_{1}^{U E^{*}}(\alpha)}{d \alpha}<0$ and $\frac{q_{2}^{U E^{*}}(\alpha)}{d \alpha}>0$.

Proof. See the Appendix.

Lemma 1 reveals an interesting strategic effect under the UE rule. As the strength of the patent (parametrized by $\alpha$ ) increases and it becomes more likely that the patent will be upheld in the court, the infringer competes more aggressively whereas the patentholder plays the role of an accommodator. The intuition is that the patent holder receives firm 2's profit when the patent is held valid. As a result, firm 1 behaves as if it had partial ownership ( $\alpha$ share) of firm 2. Firm 1 internalizes the effects of its output on firm 2's profit and behaves less aggressively compared to the standard Cournot competition. This effect is represented by an inward shift of firm 1's reaction function with $R_{1}^{U E}\left(q_{2} ; \alpha\right)<$ $R_{1}\left(q_{2}\right)$. In response, firm 2 behaves more aggressively with strategic complements.

\section{2. Competition with Uncertain Patents under the Lost Profit Damage Rule}

I now analyze how the patent-holder (firm 1) and the potential infringer (firm 2) compete under the alternative rule of "lost profit" (LP). Under this rule, the patentholder is entitled to recover lost profits due to infringement. ${ }^{10}$ Let $\pi^{M}$ be the monopoly profit

\footnotetext{
${ }^{10}$ In actual patent infringement cases, lost profits are considered an appropriate measure of patent infringement damages if the following four conditions can be established: 1. demands for the subject of intellectual property exist, 2 . acceptable noninfringing alternatives do not exist, 3 . the plaintiff have the capacity to manufacture and market the infringing products, and 4. economic damages can be quantified with reasonable probability. These four conditions are called the Panduit test. The set-up in my model satisfies all these conditions.
} 
that the patent holder would have received in the absence of any entry. Then, the patentholder solves the following problem under the LP rule:

$$
\underset{q_{1}}{\operatorname{Max}} \Pi_{1}^{L P}(\alpha)=\pi_{1}\left(q_{1}, q_{2}\right)+\alpha\left[\pi^{M}-\pi_{1}\left(q_{1}, q_{2}\right)\right]=(1-\alpha) \pi_{1}\left(q_{1}, q_{2}\right)+\alpha \pi^{M}
$$

The first order condition for firm 1's optimal output $q_{1}$ is given by

$$
\frac{\partial \pi_{1}\left(q_{1}, q_{2}\right)}{\partial q_{1}}=0
$$

which implicitly defines firm A's reaction function $q_{1}=R_{1}^{L P}\left(q_{2}\right)=R_{1}\left(q_{2}\right)$.

The potential infringer solves the following problem.

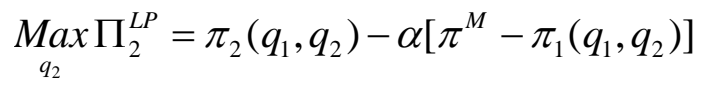

The first order condition for firm 2's optimal output $q_{2}$ is given by

$$
\frac{\partial \pi_{2}\left(q_{1}, q_{2}\right)}{\partial q_{2}}+\alpha \frac{\partial \pi_{1}\left(q_{1}, q_{2}\right)}{\partial q_{2}}=0,
$$

which implicitly defines firm 2's reaction function $q_{2}=R_{2}^{L P}\left(q_{1} ; \alpha\right)$. Thus, the strategic incentives facing the imitator in the LP regime is isomorphic to those facing a firm that has partial ownership of $\alpha$ in the rival firm. As a result, the market outcome in the LP regime is a mirror image of the one in the UE regime with the roles of the firms reversed. The Nash equilibrium royalty rates $\left[q_{1}^{L P^{*}}(\alpha), q_{2}^{L P^{*}}(\alpha)\right]$ are at the intersection of these two reaction functions.

Lemma 2. $\frac{q_{1}^{L P^{*}}(\alpha)}{d \alpha}>0$ and $\frac{q_{2}^{L P^{*}}(\alpha)}{d \alpha}<0$.

Proof. It can be proved by proceeding in a similar way as in the proof of lemma 1.

Corollary. Let $\left(q_{1}{ }^{*}, q_{2}{ }^{*}\right)$ be the unique Nash equilibrium of the game in the absence of IPR. Then, we have $q_{1}^{U E^{*}}(\alpha)<q_{1}^{*}<q_{1}^{L P^{*}}(\alpha)$ and $q_{2}^{L P^{*}}(\alpha)<q_{2} *<q_{2}^{U E^{*}}(\alpha)$ for all $\alpha \in$ $(0,1]$ 
Proof. The absence of IPR corresponds to the case of $\alpha=0$, that is, $q_{i}{ }^{*}=q_{i}^{L P *}(0)=$ $q_{i}^{U E^{*}}(0), i=1,2$. The corollary follows immediately from Lemmas 1 and 2.

\section{3. Comparison of the UE and LP Rules}

Lemma 3. $\pi_{1}\left(q_{1}^{U E^{*}}(\alpha), q_{2}^{U E^{*}}(\alpha)\right)<\pi_{1}\left(q_{1}^{*}, q_{2}^{*}\right)<\pi_{1}\left(q_{1}^{L P^{*}}(\alpha), q_{2}^{L P^{*}}(\alpha)\right)$ and $\pi_{2}\left(q_{1}^{L P^{*}}(\alpha), q_{2}^{L P^{*}}(\alpha)\right)<\pi_{2}\left(q_{1}^{*}, q_{2}^{*}\right)<\pi_{2}\left(q_{1}^{U E^{*}}(\alpha), q_{2}^{U E^{*}}(\alpha)\right)$ for all $\alpha \in(0,1]$.

Proof. We know that $q_{1}^{U E^{*}}(\alpha)<q_{1}{ }^{*}<q_{1}^{L P^{*}}(\alpha)$ and $q_{2}^{L P^{*}}(\alpha)<q_{2}{ }^{*}<q_{2}^{U E^{*}}(\alpha)$. This implies that $\pi_{1}\left(q_{1}^{U E^{*}}(\alpha), q_{2}^{U E^{*}}(\alpha)\right)<\pi_{1}\left(q_{1}^{U E^{*}}(\alpha), q_{2}{ }^{*}\right)<\pi_{1}\left(q_{1}{ }^{*}, q_{2}{ }^{*}\right)$, where the first inequality comes from the fact that $q_{2}^{U E^{*}}(\alpha)>q_{2}$ * and the second inequality follows from the definition of the Nash equilibrium. Similarly, $\pi_{1}\left(q_{1}{ }^{*}, q_{2}{ }^{*}\right)<\pi_{1}\left(q_{1}{ }^{*}, q_{2}^{L P^{*}}(\alpha)\right)<$ $\pi_{1}\left(q_{1}^{L P^{*}}(\alpha), q_{2}^{L P^{*}}(\alpha)\right)$. Once again the first inequality is due to the fact that $q_{2}^{L P^{*}}(\alpha)<q_{2}$ * and the second inequality follows from the observation that firm 1's reaction function under the lost profit doctrine is the same as the reaction function in the absence of IPR, that is, $q_{1}^{L P^{*}}(\alpha)=R_{1}^{L P}\left(q_{2}^{L P^{*}}(\alpha)\right)=R_{1}\left(q_{2}^{L P^{*}}(\alpha)\right)=\arg \max \pi_{1}\left(q_{1}, q_{2}^{L P^{*}}(\alpha)\right)$. Taken together, I have proved the first part of Lemma 3.

The second part can be proved in an analogous manner. We have $\pi_{2}\left(q_{1}^{L P^{*}}(\alpha), q_{2}^{L P^{*}}(\alpha)\right)<\pi_{2}\left(q_{1}{ }^{*}, q_{2}^{L P^{*}}(\alpha)\right)<\pi_{2}\left(q_{1}{ }^{*}, q_{2}{ }^{*}\right)$ with the first inequality coming from $q_{1}^{L P^{*}}(\alpha)>q_{1}$ * and the second inequality resulting from the definition of the Nash equilibrium. By the same token, $\pi_{2}\left(q_{1}{ }^{*}, q_{2}{ }^{*}\right)<\pi_{2}\left(q_{1}^{U E^{*}}(\alpha), q_{2}{ }^{*}\right)<$ $\pi_{2}\left(q_{1}^{U E^{*}}(\alpha), q_{2}^{U E^{*}}(\alpha)\right)$. The second inequality is from the fact that firm 2's reaction function under the unjust enrichment doctrine is the same as the reaction function in the absence of IPR, that is, $q_{2}^{U E^{*}}(\alpha)=R_{2}^{U E}\left(q_{1}^{U E^{*}}(\alpha)\right)=R_{2}\left(q_{1}^{U E^{*}}(\alpha)\right)=\underset{q_{2}}{\arg \max } \pi_{2}\left(q_{1}^{U E^{*}}(\alpha), q_{2}\right)$. Q.E.D.

Proposition 1. With the symmetric production cost structure across firms, we have $\Pi_{1}^{U E}<\Pi_{1}^{L P}$ and $\Pi_{2}^{U E}>\Pi_{2}^{L P}$, that is, the lost profit damage rule protects the patent holder 
better than the unjust enrichment rule whereas the potential infringer prefers the unjust enrichment rule to the lost profit rule.

Proof. With equal production efficiency between the patent holder and the potential infringer, we have

$$
\begin{aligned}
\Pi_{1}^{L P}(\alpha)-\Pi_{1}^{U E}(\alpha)=\{ & \left.\pi_{1}\left(q_{1}^{L P^{*}}(\alpha), q_{2}^{L P^{*}}(\alpha)\right)+\alpha\left[\pi^{M}-\pi_{1}\left(q_{1}^{L P^{*}}(\alpha), q_{2}^{L P^{*}}(\alpha)\right)\right]\right\} \\
& -\left\{\pi_{1}\left(q_{1}^{U E^{*}}(\alpha), q_{2}^{U E^{*}}(\alpha)\right)+\alpha \pi_{2}\left(q_{1}^{U E^{*}}(\alpha), q_{2}^{*}(\alpha)\right)\right\} \\
= & \alpha\left\{\pi^{M}-\left[\pi_{1}\left(q_{1}^{U E^{*}}(\alpha), q_{2}^{U E^{*}}(\alpha)\right)+\pi_{2}\left(q_{1}^{U E^{*}}(\alpha), q_{2}^{U E^{*}}(\alpha)\right)\right]\right\} \\
& +(1-\alpha)\left[\pi_{1}\left(q_{1}^{L P^{*}}(\alpha), q_{2}^{L P^{*}}(\alpha)\right)-\pi_{1}\left(q_{1}^{U E^{*}}(\alpha), q_{2}^{U E^{*}}(\alpha)\right)\right]>0
\end{aligned}
$$

The inequality above follows since $\pi^{M} \geq \pi_{1}\left(q_{1}, q_{2}\right)+\pi_{2}\left(q_{1}, q_{2}\right)$ for any combination of $\left(q_{1}, q_{2}\right)$ and $\pi_{1}\left(q_{1}^{L P^{*}}(\alpha), q_{2}^{L P^{*}}(\alpha)\right)>\pi_{1}\left(q_{1}^{U E^{*}}(\alpha), q_{2}^{U E^{*}}(\alpha)\right)$ by lemma 3 .

Similarly, we have

$$
\begin{aligned}
\Pi_{2}^{U E}(\alpha)-\Pi_{2}^{L P}(\alpha)= & {\left[(1-\alpha) \pi_{2}\left(q_{1}^{U E^{*}}(\alpha), q_{2}^{U E^{*}}(\alpha)\right)\right] } \\
& -\left\{\pi_{2}\left(q_{1}^{L P^{*}}(\alpha), q_{2}^{L P^{*}}(\alpha)\right)-\alpha\left[\pi^{M}-\pi_{1}\left(q_{1}^{L P^{*}}(\alpha), q_{2}^{L P^{*}}(\alpha)\right)\right]\right\} \\
> & (1-\alpha) \pi_{2}\left(q_{1}{ }^{*}, q_{2}{ }^{*}\right)-\left\{\pi_{2}\left(q_{1}{ }^{*}, q_{2}{ }^{*}\right)-\alpha\left[\pi^{M}-\pi_{1}\left(q_{1}^{L P^{*}}(\alpha), q_{2}^{L P^{*}}(\alpha)\right)\right]\right\} \\
= & \alpha\left[\pi^{M}-\left[\pi_{1}\left(q_{1}^{L P^{*}}(\alpha), q_{2}^{L P^{*}}(\alpha)\right)+\pi_{2}\left(q_{1}{ }^{*}, q_{2}{ }^{*}\right)\right]\right. \\
& >\alpha\left[\pi^{M}-\left[\pi_{1}\left(q_{1}{ }^{*}, q_{2}{ }^{*}\right)+\pi_{2}\left(q_{1}{ }^{*}, q_{2}{ }^{*}\right)\right]>0 .\right.
\end{aligned}
$$

The first two inequalities follow from lemma 3 and the last inequality follows from the fact that $\pi^{M}>\pi_{1}\left(q_{1}{ }^{*}, q_{2}{ }^{*}\right)+\pi_{2}\left(q_{1}{ }^{*}, q_{2}{ }^{*}\right)$.

Corollary. The LP rule provides more R\&D incentives than the UE rule.

I have not specified how the innovation takes place. I can consider two alternative scenarios. In the non-tournament case in which only one firm can invest in $R \& D$, the innovation incentives depend on the patentee's expected profit. In the 
tournament case in which the two firms engage in an R\&D race to be the first firm to innovate, the R\&D incentives typically depend on the difference between the patentee's and potential entrant's profits. ${ }^{11}$ In both scenarios, the incentives to innovate are higher under the LP rule.

\section{4. Unique Efficiencies}

The result that the lost profit damage rule provides better protection for the patent holder in subsection II.3 hinges crucially on the assumption that the two firms are equally efficient and produce a homogenous product. If the potential imitator is much superior in its production cost or produces a sufficiently differentiated product thereby expanding the market demand, the patent holder may prefer the lost profit damage rule.

To see this possibility with sufficiently differentiated products, consider an extreme case in which the product produced by the imitator creates a new market and its introduction does not affect the profit of the patent holder. In this case, there will be no lost profit for the patent holder and the imitator is not liable for any damage. In contrast, under the unjust enrichment damage rule, the patent holder would be able to recover the profit of the imitator with probability $\alpha$.

The same is true if the imitator is much superior in production efficiency vis-à-vis the patent holder. More specifically, consider a situation in which both firms produce a homogeneous product with a linear market demand of $p=A-Q$, where $Q=q_{1}+q_{2}$. Their respective constant marginal costs are given by $c_{1}$ and $c_{2}$ for firm 1 and firm 2 . If they compete in the Cournot fashion, it can be easily verified that the following holds:

$$
\begin{aligned}
& q_{1}^{L P^{*}}(\alpha)=\frac{A-2 c_{1}+c_{2}}{3-\alpha}, q_{2}^{L P^{*}}(\alpha)=\frac{(1-\alpha) A-2 c_{2}+(1+\alpha) c_{1}}{3-\alpha} \\
& q_{1}^{U E^{*}}(\alpha)=\frac{(1-\alpha) A-2 c_{1}+(1+\alpha) c_{2}}{3-\alpha}, q_{2}^{U E^{*}}(\alpha)=\frac{A-2 c_{2}+c_{1}}{3-\alpha}
\end{aligned}
$$

The patent holder's equilibrium profits under each regime are given by:

\footnotetext{
11 See Reinganum (1988) for a survey of R\&D models.
} 


$$
\begin{aligned}
& \Pi_{1}^{L P}=\alpha\left(\frac{A-c_{1}}{2}\right)^{2}+(1-\alpha)\left(\frac{A-2 c_{1}+c_{2}}{3-\alpha}\right)^{2} \\
& \Pi_{1}^{U E}=\left[\frac{(1-\alpha) A-2 c_{1}+(1+\alpha) c_{2}}{3-\alpha}\right]^{2}+\alpha\left(\frac{A-2 c_{2}+c_{1}}{3-\alpha}\right)^{2}
\end{aligned}
$$

Let $d=c_{1}-c_{2} \geq 0$ denote the efficiency advantage of the imitator and normalize $c_{2}=0$, which implies that $c_{1}=d$. It can be easily verified that $\Pi_{1}^{L P}(\alpha)-\Pi_{1}^{U E}(\alpha)<0$ if $d \geq$ A/2. In addition, we know that $\Pi_{1}^{L P}(\alpha)-\Pi_{1}^{U E}(\alpha)>0$ if $d=0$ by Proposition 1 . A straightforward calculation shows that $\frac{\partial\left[\Pi_{1}^{L P}(\alpha)-\Pi_{1}^{U E}(\alpha)\right]}{\partial d}<0$, which implies that there is a unique $d^{*} \in(0, A / 2)$ such that $\Pi_{1}^{L P}(\alpha)-\Pi_{1}^{U E}(\alpha) \geq 0$ if and only if $d \leq d^{*}$.

This result is consistent with Shankerman and Scotchmer (2000) who show that the unjust-enrichment doctrine does a better job of protecting the patent-holder in a vertical relationship between the patent-holder and the potential imitator in which only the latter has the capability to develop a commercially marketable product. ${ }^{12}$ The case considered in the Shankerman and Scotchmer is formally equivalent to the case of $d \geq A$ $\left(>d^{*}\right)$ in my setup.

\section{Welfare Analysis}

In the previous section, I investigated how the patent holder and the potential imitator behave in the output market under the damage rules of "lost profit" and "unjust enrichment” and compared their profits under the respective regimes. In this section, I analyze welfare implications of the two regimes.

I define social welfare as the sum of consumer surplus and producer surplus. Let $Q^{L P}=q_{1}^{L P^{*}}(\alpha)+q_{2}^{L P^{*}}(\alpha)$ and $Q^{U E}=q_{1}^{U E^{*}}(\alpha)+q_{2}^{U E^{*}}(\alpha)$ be the aggregate market output under the LP and UE regimes, respectively. Then

\footnotetext{
12 Shankerman and Scotchmer's (2000) result holds if infringement would not be deterred under the unjust enrichment rule in their model. They need this additional condition since they consider a certain patent with $\alpha=1$, and thus the potential infringer is indifferent between infringement and non-infringement in their setup. With a probabilistic patent, the potential imitator always has incentives to infringe under the unjust enrichment rule.
} 


$$
S W^{i}=\left[\int_{0}^{Q^{i}} P(x) d x-P\left(Q^{i}\right) Q^{i}\right]+\left[\Pi_{1}^{i}+\Pi_{2}^{i}\right]=\int_{0}^{Q^{i}} P(x) d x-c_{1} q_{1}^{i^{*}}(\alpha)-c_{2} q_{2}^{i^{*}}(\alpha),
$$

where $i=\mathrm{LP}$ or UE.

\section{1. Equal Efficiencies between the Patentholder and the Potential Imitator}

Suppose that the two firms have the same production cost of $c_{1}=c_{2}=c$. Notice that with the symmetric cost structure, $R_{1}^{L P}(\cdot ; \alpha)=R_{1}(\cdot)=R_{2}(\cdot)=R_{2}^{U E}(\cdot ; \alpha)$ and $R_{1}^{U E}(\cdot ; \alpha)=R_{2}^{L P}(\cdot ; \alpha)$, that is, the reaction function of the patentholder under LP is identical to that of the potential imitator under UE and the reaction function of the patentholder under UE is identical to that of the potential imitator under LP. As a result,

we have $q_{1}^{L P^{*}}(\alpha)=q_{2}^{U E^{*}}(\alpha)$ and $q_{2}^{L P^{*}}(\alpha)=q_{1}^{U E^{*}}(\alpha)$. In other words, only the roles of the firms are reversed across the two regimes. As a result, the total outputs in both regimes are identical, i.e., $Q^{L P}=q_{1}^{L P^{*}}(\alpha)+q_{2}^{L P^{*}}(\alpha)=q_{1}^{U E^{*}}(\alpha)+q_{2}^{U E^{*}}(\alpha)=Q^{U E}$.

Proposition 2. Ex post innovation, the two damage rules yield the same social surplus.

So far, I have not focused on development incentives and have taken the innovation as given. Since the two damage rules provide the same social surplus with equal efficiencies between the patent holder and potential imitator, I can conclude that LP is superior to UE if the development incentives are taken into account.

\section{III.2. Unique Efficiencies}

I now investigate welfare implications in the event of cost asymmetry between the patentholder and the potential imitator. With cost asymmetry, there are two complications. First, the total output need not be identical across the two regimes. In addition, even if the aggregate outputs are the same, the distribution of the market shares affect the total production costs.

It is difficult to have any analytical results on the comparison of the total outputs and welfare across the regimes in the general set-up. By making assumptions about the specific form of the market demand curve, one can make quantitative assessments of the 
aggregate outputs across the regimes. I thus consider a linear demand curve to address the welfare question. Assume $p=A-Q$, where $Q=q_{1}+q_{2}$ as in subsection II.4. Then,

$$
\begin{aligned}
& Q^{L P}=q_{1}^{L P^{*}}(\alpha)+q_{2}^{L P^{*}}(\alpha)=\frac{(2-\alpha) A-(1-\alpha) c_{1}-c_{2}}{3-\alpha} \\
& Q^{U E}=q_{1}^{U E^{*}}(\alpha)+q_{2}^{U E^{*}}(\alpha)=\frac{(2-\alpha) A-c_{1}-(1-\alpha) c_{2}}{3-\alpha}
\end{aligned}
$$

The following result immediately follows.

Lemma 4. $Q^{L P}=q_{1}^{L P^{*}}(\alpha)+q_{2}^{L P^{*}}(\alpha)>Q^{U E}=q_{1}^{U E^{*}}(\alpha)+q_{2}^{U E^{*}}(\alpha)$ if and only if $c_{1}>c_{2}$.

As a result, with a linear demand curve, the market price under the LP regime is lower than that under the UE regime if the patenholder has a higher production cost than the potential imitator. However, this does not imply that the welfare under the LP regime is higher than that under the UE regime when $c_{1}>c_{2}$. The reason is that the patentholder produces a disproportionately larger share than the potential imitator under the LP regime, which is relatively inefficient when the patent holder has a higher production cost. Indeed, as the next Proposition demonstrates, with a linear demand curve the inefficiency in production outweighs allocative efficiency of the LP regime vis-à-vis the UE regime when $c_{1}>c_{2}$.

Proposition 3. With a linear demand, social welfare is higher in the LP (UE) regime if $c_{1}<(>) c_{2}$.

Proof. With a linear demand of $p=A-Q$, we have

$$
\begin{aligned}
S W^{L P} & =\int_{0}^{Q^{L P}} P(x) d x-c_{1} q_{1}^{L P^{*}}(\alpha)-c_{2} q_{2}^{L P^{*}}(\alpha) \\
& =\frac{\left[(4-\alpha) A+(1-\alpha) c_{1}+c_{2}\right]\left[(2-\alpha) A-(1-\alpha) c_{1}-c_{2}\right]}{2(3-\alpha)^{2}} \\
& -c_{1}\left(\frac{A-2 c_{1}+c_{2}}{3-\alpha}\right)-c_{2}\left(\frac{(1-\alpha) A-2 c_{2}+(1+\alpha) c_{1}}{3-\alpha}\right)
\end{aligned}
$$




$$
\begin{aligned}
S W^{U E} & =\int_{0}^{Q^{U E}} P(x) d x-c_{1} q_{1}^{U E^{*}}(\alpha)-c_{2} q_{2}^{U E^{*}}(\alpha) \\
& =\frac{\left[(4-\alpha) A+c_{1}+(1-\alpha) c_{2}\right]\left[(2-\alpha) A-c_{1}-(1-\alpha) c_{2}\right]}{2(3-\alpha)^{2}} \\
& -c_{1}\left(\frac{(1-\alpha) A-2 c_{1}+(1+\alpha) c_{2}}{3-\alpha}\right)-c_{2}\left(\frac{A-2 c_{2}+c_{1}}{3-\alpha}\right)
\end{aligned}
$$

Therefore, we have

$$
S W^{L P}-S W^{U E}=\frac{-\alpha\left[2(2-\alpha) A+(2+\alpha)\left(c_{1}+c_{2}\right)\right]}{2(3-\alpha)^{2}}\left(c_{1}-c_{2}\right) \text {, which proves the claim. }
$$

The result in Proposition 3 also has implications for welfare analysis of the effects of partial ownership of competitors' assets in an industry. ${ }^{13}$ It suggests that if firms are asymmetric in their efficiencies and sizes, it would be better for social welfare for a small and inefficient firm to have partial ownership of a large and efficient firm rather than the other way around, as usually is the case. The reason is that the small firm will restrict its output after acquiring partial ownership and the large firm will expand its output in response with industry output being shifted toward the firm with lower marginal costs. ${ }^{14}$

\section{How Reasonable is the "Reasonable” Royalty Rate?}

When the lost profits or actual damages from the infringement cannot be proved or deemed to be too speculative, the court accepts a "reasonable" royalty rate as an alternative measure of damage. ${ }^{15}$ Georgia-Pacific Corp. v. United States Plywood Corp. established 15 factors that can be considered in determining the reasonable royalty rate. Not surprisingly, in actual patent cases licensing experts on the plaintiff side tend to identify the factors that lead to high royalty rates while the infringer side points towards

\footnotetext{
13 For an analysis of the competitive effects of partial equity interests in an oligopolistic industry, see Reynolds and Snapp (1986), Farrell and Shapiro (1990), Kwoka (1992), and Reitman (1994).

14 Farrell and Shapiro (1990) make a similar observation. The most literature on partial ownership assumes symmetric firms and emphasizes the potential for collusion that such ownership entails. In contrast, Farrell and Shapiro show that welfare may well rise as ownership becomes more concentrated with a small firm buys part of a bigger firm, due to more efficient output distributions between heterogeneous firms.

15 More precisely, the law specifies that any award cannot be lower than the reasonable royalty rate.
} 
the factors that lead to low royalty rate. As a result, this doctrine has proved difficult to implement in a consistent and predictable manner (Conley, 1987). However, the essence of the rule is considered as a "hypothetical license" approach that defines the reasonable royalty rate as " $[\mathrm{t}]$ he amount that a licensor (such as the patentee) and a licensee (such as the infringer) would have agreed upon (at the time of the infringement began) if both had been reasonably and voluntarily trying to reach an agreement.”

In considering the counterfactual scenario to calculate what the infringer should and would have paid with a hypothetical negotiation between the infringer and patent holder, it should be recognized that the negotiation between them takes place in the shadow of litigation and the damage rule in case of infringement. More precisely, let $\tilde{r}^{e}$ be the "reasonable" royalty rate that is expected to be paid by the infringer without licensing. This expected royalty rate sets the expected payoffs of each party in the absence of licensing, which serves as the threat point in the bargaining. The potential infringer will choose its output to solve:

$$
\begin{aligned}
\underset{q_{2}}{\operatorname{Max}} & \Pi_{2}^{R R}(\alpha)=\pi_{2}\left(q_{1}, q_{2}\right)-\alpha \tilde{r}^{e} q_{2}=\left[P_{2}\left(q_{1}, q_{2}\right)-c_{2}\right] q_{2}-\alpha \tilde{r}^{e} q_{2} \\
& =\left[P_{2}\left(q_{1}, q_{2}\right)-\left(c_{2}+\alpha \tilde{r}^{e}\right)\right] q_{2}
\end{aligned}
$$

Thus, firm 2 behaves as if its marginal cost were $\left(c_{2}+\alpha \tilde{r}^{e}\right)$. Let $\pi_{i}^{*}\left(c_{1}, c_{2}\right)$ be the standard Cournot equilibrium profit for firm $i$ when firm 1's and 2's costs are given by $c_{1}$ and $c_{2}$, respectively. Then, firm 2's expected payoff from infringement under the reasonable royalty rate regime is given by $\pi_{2} *\left(c_{1}, c_{2}+\alpha \tilde{r}^{e}\right)$. This payoff serves as a reference point in the bargaining between the patentholder and the potential infringer. For simplicity and concreteness, let me assume that the negotiation takes place in the form of a take-it-or-leave-it offer by the patent holder. ${ }^{16}$ Then, the royalty rate in a hypothetical negotiation will be set to maximize:

\footnotetext{
16 Allowing a more balanced bargaining power between the patent holder and the potential infringer as in the generalized Nash bargaining solution does not change any qualitative results.
} 


$$
\begin{aligned}
\operatorname{Max}_{r} \Pi_{1}^{R R}(\alpha)= & \pi_{1}^{*}\left(c_{1}, c_{2}+r\right)+r q_{2}\left(c_{1}, c_{2}+r\right) \\
& \text { subject to }
\end{aligned}
$$

$$
\pi_{2} *\left(c_{1}, c_{2}+r\right) \geq \pi_{2} *\left(c_{1}, c_{2}+\alpha \tilde{r}^{e}\right)
$$

Notice that $\frac{d \Pi_{1}^{R R}(\alpha)}{d r}=\frac{\partial \pi_{1}^{*}\left(c_{1}, c_{2}+r\right)}{\partial c_{2}}+q_{2}\left(c_{1}, c_{2}+r\right)+r \frac{\partial q_{2}\left(c_{1}, c_{2}+r\right)}{\partial c_{2}}$. Notice that $\frac{\partial \pi_{1}^{*}\left(c_{1}, c_{2}+r\right)}{\partial c_{2}}=P^{\prime} \frac{\partial q_{2}\left(c_{1}, c_{2}+r\right)}{\partial c_{2}} q_{1}\left(c_{1}, c_{2}+r\right)$ by the envelope theorem and the first order condition for firm 1's profit maximization. Thus, we have $\frac{d \Pi_{1}^{R R}(\alpha)}{d r}=-(P-c-r) \frac{\partial q_{2}\left(c_{1}, c_{2}+r\right)}{\partial c_{2}}+q_{2}\left(c_{1}, c_{2}+r\right)>0$. This implies that the constraint will be binding. Let the solution to the above problem be $\tilde{r}$. Then, it is clear that $\tilde{r}=$ $\alpha \tilde{r}^{e}$. The "reasonable" royalty rate requires that $\tilde{r}^{e}=\tilde{r}$, which implies that $\tilde{r}=\alpha \tilde{r}$. This condition can be satisfied only when $\alpha=1$, that is, patent protection is perfect and there is no uncertainty about the validity of the patent. In fact, when $\alpha=1$, we have a continuum of "reasonable" royalty rates that are consistent with the logic. However, if the patent is probabilistic with $\alpha \in(0,1)$, the concept of a "reasonable" royalty rate that presumes a hypothetical negotiation is flawed since there is no "reasonable" royalty rate that is consistent with the logic.

Proposition 4. When the patent is probabilistic, there is no "reasonable" royalty rate that is consistent with the logic. When the patent is ironclad $(\alpha=1)$, the concept suffers from an opposite problem, that is, a multiplicity of reasonable royalty rate.

Shankerman and Scotchmer (2001) also recognize the circularity and selfreferential nature of equilibrium in the logic of this doctrine. ${ }^{17}$ In their model, they consider ironclad patents in which intellectual property rights are enforced with certainty. In such a framework, they show that licensee fees and prospective damages are equal and self-enforcing. Due to this bootstrapping nature of equilibrium, there is a continuum of

\footnotetext{
17 To emphasize the circularity of the logic, they avoid using the term "reasonable royalty" and instead refer to "lost royalty."
} 
reasonable royalty rates that are consistent with the logic. However, when there is uncertainty about the validity of patents, I point out that there is a more serious and opposite problem arises, that is, there is no reasonable royalty rate that is consistent with the logic.

The inconsistency of the logic in the case of uncertain patents is not difficult to understand. The hypothetical ex ante negotiation is supposed to take place under uncertainty about the validity of the patent (i.e. $\alpha \in(0,1)$ ), whereas the damage liability consideration is relevant only in the ex post case that the patent is found to be valid $(\alpha=1)$. As the value of a winning lottery ticket cannot be equal to the value of a lottery ticket before the drawing, the value of the patent that is certified to be valid in the court cannot be equal to the value of the patent with uncertain validity. However, the equivalence between these two is exactly what the "reasonable" royalty rate doctrine implicitly requires.

\section{Ex Ante Licensing Contract}

In section II, I analyzed how the lost-profit and unjust-enrichment rules affect market competition between the patentholder and the infringer. In this section, I allow ex ante licensing and analyze how different damage rules affect the terms of ex ante licensing contracting with frictionless bargaining. In this case, the equilibrium profits under respective damage rules serve as the threat points in the bargaining game between the patentholder and the potential infringer as in the analysis of Shankerman and Scotchmer (2001).

As in the previous section, let me assume that the negotiation takes place in the form of a take-it-or-leave-it offer by the patent holder. ${ }^{18}$ The royalty rate in a hypothetical negotiation will be set to maximize:

$$
\begin{aligned}
\underset{r, F}{\operatorname{Max}} \Pi_{1}^{L}(\alpha)= & \pi_{1}^{*}\left(c_{1}, c_{2}+r\right)+r q_{2}\left(c_{1}, c_{2}+r\right)+F \\
& \text { subject to }
\end{aligned}
$$

\footnotetext{
18 Once again, allowing a more balanced bargaining power between the patent holder and the potential infringer as in the generalized Nash bargaining solution does not change any qualitative results.
} 


$$
\pi_{2}^{*}\left(c_{1}, c_{2}+r\right)-F \geq \Pi_{2}^{K}(\alpha), K=\mathrm{UE}, \mathrm{LP}
$$

It is clear that the incentive constraint holds with equality with $F=$ $\pi_{2}^{*}\left(c_{1}, c_{2}+r\right)-\Pi_{2}^{K}(\alpha)$. Thus, we can rewrite the problem as:

$$
\operatorname{Max}_{r} \Pi_{1}^{L}(\alpha)=\pi_{1}^{*}\left(c_{1}, c_{2}+r\right)+\pi_{2} *\left(c_{1}, c_{2}+r\right)+r q_{2}\left(c_{1}, c_{2}+r\right)-\Pi_{2}^{K}(\alpha)
$$

Lemma 5. Let $\bar{r}$ be the lowest $r$ such that $q_{2}\left(c_{1}, c_{2}+r\right)=0$, that is, the minimum royalty rate that induces exit by firm 2 . Then,

$\Pi_{1}^{L}(\alpha)=\pi_{1}^{*}\left(c_{1}, c_{2}+r\right)+\pi_{2} *\left(c_{1}, c_{2}+r\right)+r q_{2}\left(c_{1}, c_{2}+r\right)-\Pi_{2}^{K}(\alpha)$ is strictly increasing in $r$ for $r \in[0, \bar{r})$

Proof. The first order condition with respect to $r$ is given by:

$$
\frac{d \Pi_{1}^{L}(\alpha)}{d r}=\frac{\partial \pi_{1}^{*}\left(c_{1}, c_{2}+r\right)}{\partial c_{2}}+\frac{\partial \pi_{2} *\left(c_{1}, c_{2}+r\right)}{\partial c_{2}}+q_{2}\left(c_{1}, c_{2}+r\right)+r \frac{\partial q_{2}\left(c_{1}, c_{2}+r\right)}{\partial c_{2}}=0
$$

By the envelope theorem, $\frac{\partial \pi_{1}^{*}\left(c_{1}, c_{2}+r\right)}{\partial c_{2}}=P^{\prime} \frac{\partial q_{2}\left(c_{1}, c_{2}+r\right)}{\partial c_{2}} q_{1}\left(c_{1}, c_{2}+r\right)$ and

$\frac{\partial \pi_{2}^{*}\left(c_{1}, c_{2}+r\right)}{\partial c_{2}}=P^{\prime} \frac{\partial q_{1}\left(c_{1}, c_{2}+r\right)}{\partial c_{2}} q_{2}\left(c_{1}, c_{2}+r\right)-q_{2}\left(c_{1}, c_{2}+r\right)$. Therefore, we have $\frac{d \Pi_{1}^{L}(\alpha)}{d r}=P^{\prime} \frac{\partial q_{2}\left(c_{1}, c_{2}+r\right)}{\partial c_{2}} q_{1}\left(c_{1}, c_{2}+r\right)+P^{\prime} \frac{\partial q_{1}\left(c_{1}, c_{2}+r\right)}{\partial c_{2}} q_{2}\left(c_{1}, c_{2}+r\right)+r \frac{\partial q_{2}\left(c_{1}, c_{2}+r\right)}{\partial c_{2}}$.

By the first order condition for profit maximization, we know that $P^{\prime} q_{1}\left(c_{1}, c_{2}+r\right)=c$ and $P^{\prime} q_{2}\left(c_{1}, c_{2}+r\right)=c+r$. Therefore, we can rewrite $\frac{d \Pi_{1}^{L}(\alpha)}{d r}$ as $\frac{d \Pi_{1}^{L}(\alpha)}{d r}=-(P-c-r)\left[\frac{\partial q_{1}\left(c_{1}, c_{2}+r\right)}{\partial c_{2}}+\frac{\partial q_{2}\left(c_{1}, c_{2}+r\right)}{\partial c_{2}}\right]$, which is positive since $P-c-r>0$ for all $r<\bar{r}$ and the expression in the square bracket is negative. This result implies that the patentholder offers a very high royalty rate to induce firm 2 to exit from the market in exchange for a reverse lump sum payment of $\Pi_{2}^{K}(\alpha)$ to the potential 
infringer. This contract will sustain a monopoly outcome in the market. ${ }^{19}$ I thus assume that antitrust authorities do not allow reverse payments (negative $F$ ).

With the constraint that $F \geq 0$, the patentholder will set $F=0$ and choose the highest $r$ such that $\pi_{2} *\left(c_{1}, c_{2}+r\right) \geq \Pi_{2}^{K}(\alpha)$. Since $\pi_{2} *\left(c_{1}, c_{2}+r\right)$ is decreasing in $r$, we can find a unique $r$ that satisfies $\pi_{2}^{*}\left(c_{1}, c_{2}+r\right)=\Pi_{2}^{K}(\alpha)$.

Proposition 5. Let $\left(r^{U E}, F^{U E}\right)$ and $\left(r^{L P}, F^{L P}\right)$ denote the equilibrium ex ante licensing contract under alternative regimes of UE and LP. If the reverse payment is not allowed by antitrust authorities, $F^{U E}=F^{L P}=0$ and $r^{K}$ is uniquely defined by $\pi_{2} *\left(c_{1}, c_{2}+r^{K}\right)=\Pi_{2}^{K}(\alpha)$, where $K=\mathrm{UE}$, LP, with $r^{U E}<r^{L P}$.

\section{Concluding Remarks}

I have developed a simple model of product innovation in which I analyzed how different damage rules in patent infringement cases shape competition when intellectual property rights are probabilistic. In particular, I compared two infringement damage rules used in the US - the unjust enrichment rule and the lost profit rule. Ex post innovation, these two rules are equivalent in terms of outputs and social welfare if the patentholder and the potential infringer are equally efficient. However, with asymmetric inefficiency and a linear demand, the LP rule generates higher social welfare than the UE rule if and only if the imitator is more efficient than the patentholder. The analysis has implications for the effects of partial ownership in the industry since the competitive effects of damage rules are isomorphic to those of partial ownership. It also points out the logical inconsistency in the concept of the "reasonable royalty rates" when intellectual property rights are not ironclad.

19 See Farrell and Shapiro (2005). 


\section{Appendix}

\section{Proof of Lemma 1:}

Totally differentiating (A1) and (A2) gives us the following expressions.

$$
\begin{gathered}
\frac{\partial^{2} \pi_{1}}{\partial q_{1}{ }^{2}} d q_{1}+\frac{\partial^{2} \pi_{1}}{\partial q_{1} \partial q_{2}} d q_{2}+\alpha\left[\frac{\partial^{2} \pi_{2}}{\partial q_{1}{ }^{2}} d q_{1}+\frac{\partial^{2} \pi_{2}}{\partial q_{1} \partial q_{2}} d q_{2}\right]+\frac{\partial \pi_{2}}{\partial q_{1}} d \alpha=0 \\
\frac{\partial^{2} \pi_{2}}{\partial q_{1} \partial q_{2}} d q_{1}+\frac{\partial^{2} \pi_{2}}{\partial q_{2}{ }^{2}} d q_{2}=0
\end{gathered}
$$

To derive comparative statics result with respect to $\alpha$, we can write the expressions above in the following matrix form.

$$
\left[\begin{array}{cc}
\frac{\partial^{2} \pi_{1}}{\partial q_{1}{ }^{2}}+\alpha \frac{\partial^{2} \pi_{2}}{\partial q_{1}{ }^{2}} & \frac{\partial^{2} \pi_{1}}{\partial q_{1} \partial q_{2}}+\frac{\partial^{2} \pi_{2}}{\partial q_{1} \partial q_{2}} \\
\frac{\partial^{2} \pi_{2}}{\partial q_{1} \partial q_{2}} & \frac{\partial^{2} \pi_{2}}{\partial q_{2}{ }^{2}}
\end{array}\right]\left[\begin{array}{c}
\frac{d q_{1}^{U E}}{\partial \alpha} \\
\frac{d q_{2}^{U E}}{\partial \alpha}
\end{array}\right]=\left[\begin{array}{c}
-\frac{\partial \pi_{2}}{\partial q_{1}} \\
0
\end{array}\right]
$$

By applying Cramer’s rule, we can derive

$\frac{q_{1}^{U E^{*}}(\alpha)}{d \alpha}=\frac{\left|\begin{array}{cc}-\frac{\partial \pi_{2}}{\partial q_{1}} & \frac{\partial^{2} \pi_{1}}{\partial q_{1} \partial q_{2}}+\frac{\partial^{2} \pi_{2}}{\partial q_{1} \partial q_{2}}\end{array}\right|}{0} \quad \frac{\frac{\partial^{2} \pi_{2}}{\partial q_{2}{ }^{2}}}{|A|}=\frac{-\frac{\partial \pi_{2}}{\partial q_{1}} \frac{\partial^{2} \pi_{2}}{\partial q_{2}{ }^{2}}}{|A|}$

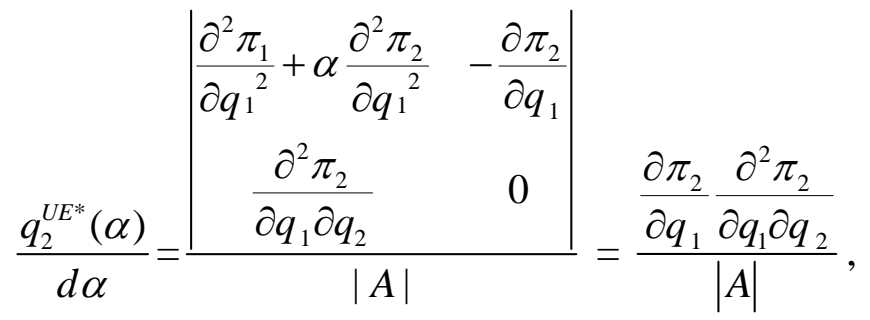




$$
\begin{aligned}
& \text { where }|\mathrm{A}|=\left|\begin{array}{cc}
\frac{\partial^{2} \pi_{1}}{\partial q_{1}{ }^{2}}+\alpha \frac{\partial^{2} \pi_{2}}{\partial q_{1}{ }^{2}} & \frac{\partial^{2} \pi_{1}}{\partial q_{1} \partial q_{2}}+\frac{\partial^{2} \pi_{2}}{\partial q_{1} \partial q_{2}} \\
\frac{\partial^{2} \pi_{2}}{\partial q_{1} \partial q_{2}} & \frac{\partial^{2} \pi_{2}}{\partial q_{2}{ }^{2}}
\end{array}\right|>0 \text { by the stability condition. Since } \\
& \frac{\partial^{2} \pi_{2}}{\partial q_{2}{ }^{2}}<0 \text { by the second order condition and } \frac{\partial^{2} \pi_{2}}{\partial q_{1} \partial q_{2}}<0 \text { by strategic substitutes, we have } \\
& \frac{q_{1}^{U E^{*}}(\alpha)}{d \alpha}<0 \text { and } \frac{q_{2}^{U E^{*}}(\alpha)}{d \alpha}>0 \\
& \text { Q.E.D. }
\end{aligned}
$$




\section{References}

Anton, James J. and Yao, Dennis A., "Finding 'Lost' Profits: An Equilibrium Analysis of Patent Infringement Damages,” Journal of Law, Economics and Organization, forthcoming.

Ayres, Ian and Klemperer, Paul, “Limiting Patnetee’s Market Powere without Reducing Innovation Incentives: The Perverse Benefits of Uncertainty and Non-Injunctive Remedies,” Michigan Law Review, 1999, pp. 985-1033.

Blair, Roger D. and Cotter, Thomas F., “An Economic Analysis of Damage Rules in Intellectual Property Law,” William and Mary Law Review, 1998, pp. 1585-1694.

Crampes, Claude and Langinier, Corinne, "Litigation and Settlement in Patent Infringement Cases,” Rand Journal of Economics, 2002, pp. 258-274.

Farrell, Joseph and Shapiro, Carl, “Asset Ownership and Market Structure in Oligopoly,” Rand Journal of Economics, 1990, pp. 275-292.

Farrell, Joseph and Shapiro, Carl, “How Strong Are Weak Patents?” unpublished manuscript, 2005.

Kwoka, John E., “The Output and Profit Effects of Horizontal Joint Ventures,” Journal of Industrial Economics, 1992, pp. 325-338.

Lemley, Mark A. and Shapiro, Carl, “Probabilistic Patent,” Journal of Economic Perspectives, 2005, pp. 75-98.

Pincus, Laura B., "The Computation of Damages in Patent Infringement Actions,” 1991, Harvard Journal of Law and Technology, pp. 95-143.

Reinganum, Jennifer, “The Timing of Innovation: Research, Development, and Diffusion,” in R. Schmalensee and R. Willig (eds.), Handbook of Industrial Organization, 1989, vol. 1, pp. 849-908, Elsevier.

Reitman, David, "Partial Ownership Arrangements and the Potential for Collusion," Journal of Industrial Economics, 1994, pp. 313-322.

Reynolds, Robert J. and Snapp, Bruce R., "The Competitive Effects of Partial Equity Interests and Joint Ventures,” International Journal of Industrial Organization, 1986, pp. 141-153.

Schankerman, Mark and Scotchmer, Suzanne, "Damages and Injunctions in Protecting Intellectual Property,” Rand Journal of Economics, 2001, pp. 199-220. 


\section{CESifo Working Paper Series}

(for full list see www.cesifo-group.de)

1713 Marc-Andreas Muendler and Sascha O. Becker, Margins of Multinational Labor Substitution, May 2006

1714 Surajeet Chakravarty and W. Bentley MacLeod, Construction Contracts (or "How to Get the Right Building at the Right Price?”), May 2006

1715 David Encaoua and Yassine Lefouili, Choosing Intellectual Protection: Imitation, Patent Strength and Licensing, May 2006

1716 Chris van Klaveren, Bernard van Praag and Henriette Maassen van den Brink, Empirical Estimation Results of a Collective Household Time Allocation Model, May 2006

1717 Paul De Grauwe and Agnieszka Markiewicz, Learning to Forecast the Exchange Rate: Two Competing Approaches, May 2006

1718 Sijbren Cnossen, Tobacco Taxation in the European Union, May 2006

1719 Marcel Gérard and Fernando Ruiz, Interjurisdictional Competition for Higher Education and Firms, May 2006

1720 Ronald McKinnon and Gunther Schnabl, China's Exchange Rate and International Adjustment in Wages, Prices, and Interest Rates: Japan Déjà Vu?, May 2006

1721 Paolo M. Panteghini, The Capital Structure of Multinational Companies under Tax Competition, May 2006

1722 Johannes Becker, Clemens Fuest and Thomas Hemmelgarn, Corporate Tax Reform and Foreign Direct Investment in Germany - Evidence from Firm-Level Data, May 2006

1723 Christian Kleiber, Martin Sexauer and Klaus Waelde, Bequests, Taxation and the Distribution of Wealth in a General Equilibrium Model, May 2006

1724 Axel Dreher and Jan-Egbert Sturm, Do IMF and World Bank Influence Voting in the UN General Assembly?, May 2006

1725 Swapan K. Bhattacharya and Biswa N. Bhattacharyay, Prospects of Regional Cooperation in Trade, Investment and Finance in Asia: An Empirical Analysis on BIMSTEC Countries and Japan, May 2006

1726 Philippe Choné and Laurent Linnemer, Assessing Horizontal Mergers under Uncertain Efficiency Gains, May 2006

1727 Daniel Houser and Thomas Stratmann, Selling Favors in the Lab: Experiments on Campaign Finance Reform, May 2006 
1728 E. Maarten Bosker, Steven Brakman, Harry Garretsen and Marc Schramm, A Century of Shocks: The Evolution of the German City Size Distribution 1925 - 1999, May 2006

1729 Clive Bell and Hans Gersbach, Growth and Enduring Epidemic Diseases, May 2006

1730 W. Bentley MacLeod, Reputations, Relationships and the Enforcement of Incomplete Contracts, May 2006

1731 Jan K. Brueckner and Ricardo Flores-Fillol, Airline Schedule Competition: ProductQuality Choice in a Duopoly Model, May 2006

1732 Kerstin Bernoth and Guntram B. Wolff, Fool the Markets? Creative Accounting, Fiscal Transparency and Sovereign Risk Premia, May 2006

1733 Emmanuelle Auriol and Pierre M. Picard, Government Outsourcing: Public Contracting with Private Monopoly, May 2006

1734 Guglielmo Maria Caporale and Luis A. Gil-Alana, Modelling Structural Breaks in the US, UK and Japanese Unemployment Rates, May 2006

1735 Emily J. Blanchard, Reevaluating the Role of Trade Agreements: Does Investment Globalization Make the WTO Obsolete?, May 2006

1736 Per Engström and Bertil Holmlund, Tax Evasion and Self-Employment in a High-Tax Country: Evidence from Sweden, May 2006

1737 Erkki Koskela and Mikko Puhakka, Cycles and Indeterminacy in Overlapping Generations Economies with Stone-Geary Preferences, May 2006

1738 Saku Aura and Thomas Davidoff, Supply Constraints and Housing Prices, May 2006

1739 Balázs Égert and Ronald MacDonald, Monetary Transmission Mechanism in Transition Economies: Surveying the Surveyable, June 2006

1740 Ben J. Heijdra and Ward E. Romp, Ageing and Growth in the Small Open Economy, June 2006

1741 Robert Fenge and Volker Meier, Subsidies for Wages and Infrastructure: How to Restrain Undesired Immigration, June 2006

1742 Robert S. Chirinko and Debdulal Mallick, The Elasticity of Derived Demand, Factor Substitution and Product Demand: Corrections to Hicks' Formula and Marshall's Four Rules, June 2006

1743 Harry P. Bowen, Haris Munandar and Jean-Marie Viaene, Evidence and Implications of Zipf's Law for Integrated Economies, June 2006

1744 Markku Lanne and Helmut Luetkepohl, Identifying Monetary Policy Shocks via Changes in Volatility, June 2006 
1745 Timo Trimborn, Karl-Josef Koch and Thomas M. Steger, Multi-Dimensional Transitional Dynamics: A Simple Numberical Procedure, June 2006

1746 Vivek H. Dehejia and Yiagadeesen Samy, Labor Standards and Economic Integration in the European Union: An Empirical Analysis, June 2006

1747 Carlo Altavilla and Paul De Grauwe, Forecasting and Combining Competing Models of Exchange Rate Determination, June 2006

1748 Olaf Posch and Klaus Waelde, Natural Volatility, Welfare and Taxation, June 2006

1749 Christian Holzner, Volker Meier and Martin Werding, Workfare, Monitoring, and Efficiency Wages, June 2006

1750 Steven Brakman, Harry Garretsen and Charles van Marrewijk, Agglomeration and Aid, June 2006

1751 Robert Fenge and Jakob von Weizsäcker, Mixing Bismarck and Child Pension Systems: An Optimum Taxation Approach, June 2006

1752 Helge Berger and Michael Neugart, Labor Courts, Nomination Bias, and Unemployment in Germany, June 2006

1753 Chris van Klaveren, Bernard van Praag and Henriette Maassen van den Brink, A Collective Household Model of Time Allocation - a Comparison of Native Dutch and Immigrant Households in the Netherlands, June 2006

1754 Marko Koethenbuerger, Ex-Post Redistribution in a Federation: Implications for Corrective Policy, July 2006

1755 Axel Dreher, Jan-Egbert Sturm and Heinrich Ursprung, The Impact of Globalization on the Composition of Government Expenditures: Evidence from Panel Data, July 2006

1756 Richard Schmidtke, Private Provision of a Complementary Public Good, July 2006

1757 J. Atsu Amegashie, Intentions and Social Interactions, July 2006

1758 Alessandro Balestrino, Tax Avoidance, Endogenous Social Norms, and the Comparison Income Effect, July 2006

1759 Øystein Thøgersen, Intergenerational Risk Sharing by Means of Pay-as-you-go Programs - an Investigation of Alternative Mechanisms, July 2006

1760 Pascalis Raimondos-Møller and Alan D. Woodland, Steepest Ascent Tariff Reforms, July 2006

1761 Ronald MacDonald and Cezary Wojcik, Catching-up, Inflation Differentials and Credit Booms in a Heterogeneous Monetary Union: Some Implications for EMU and new EU Member States, July 2006 
1762 Robert Dur, Status-Seeking in Criminal Subcultures and the Double Dividend of ZeroTolerance, July 2006

1763 Christa Hainz, Business Groups in Emerging Markets - Financial Control and Sequential Investment, July 2006

1764 Didier Laussel and Raymond Riezman, Fixed Transport Costs and International Trade, July 2006

1765 Rafael Lalive, How do Extended Benefits Affect Unemployment Duration? A Regression Discontinuity Approach, July 2006

1766 Eric Hillebrand, Gunther Schnabl and Yasemin Ulu, Japanese Foreign Exchange Intervention and the Yen/Dollar Exchange Rate: A Simultaneous Equations Approach Using Realized Volatility, July 2006

1767 Carsten Hefeker, EMU Enlargement, Policy Uncertainty and Economic Reforms, July 2006

1768 Giovanni Facchini and Anna Maria Mayda, Individual Attitudes towards Immigrants: Welfare-State Determinants across Countries, July 2006

1769 Maarten Bosker and Harry Garretsen, Geography Rules Too! Economic Development and the Geography of Institutions, July 2006

1770 M. Hashem Pesaran and Allan Timmermann, Testing Dependence among Serially Correlated Multi-category Variables, July 2006

1771 Juergen von Hagen and Haiping Zhang, Financial Liberalization in a Small Open Economy, August 2006

1772 Alessandro Cigno, Is there a Social Security Tax Wedge?, August 2006

1773 Peter Egger, Simon Loretz, Michael Pfaffermayr and Hannes Winner, Corporate Taxation and Multinational Activity, August 2006

1774 Jeremy S.S. Edwards, Wolfgang Eggert and Alfons J. Weichenrieder, The Measurement of Firm Ownership and its Effect on Managerial Pay, August 2006

1775 Scott Alan Carson and Thomas N. Maloney, Living Standards in Black and White: Evidence from the Heights of Ohio Prison Inmates, 1829 - 1913, August 2006

1776 Richard Schmidtke, Two-Sided Markets with Pecuniary and Participation Externalities, August 2006

1777 Ben J. Heijdra and Jenny E. Ligthart, The Transitional Dynamics of Fiscal Policy in Small Open Economies, August 2006

1778 Jay Pil Choi, How Reasonable is the 'Reasonable' Royalty Rate? Damage Rules and Probabilistic Intellectual Property Rights, August 2006 